\title{
Effects of dietary Kleinhovia hospita and Leucaena leucocephala leaves on rumen fermentation and microbial population in goats fed treated rice straw
}

\author{
Muideen Adewale Ahmed ${ }^{1} \cdot$ Kazeem Dauda Adeyemi $^{1} \cdot$ Mohamed Faseleh Jahromi $^{2}$. \\ Shokri Jusoh ${ }^{1}$ - Abdul Razak Alimon ${ }^{1,2}$ - Anjas Asmara Samsudin ${ }^{1}$ (D)
}

Received: 12 May 2017 / Accepted: 17 August 2017 / Published online: 28 August 2017

(C) The Author(s) 2017. This article is an open access publication

\begin{abstract}
The effects of partial replacement of dietary protein by forages on rumen fermentation and microbiology in goats were examined. Four fistulated Boer bucks were used in a $4 \times 4$ Latin square design. The goats were fed $60 \%$ of ureatreated rice straw and $40 \%$ dietary treatment (Kleinhovia hospita (KH), Leucaena leucocephala (LL), mixture of $K$. hospita with L. leucocephala (KHLL)) and concentrate as the control. Rumen fluid from the animals was collected at 0 , $2,4,6$, and $12 \mathrm{~h}$ postprandial for analysis. The KHLL diet had a greater $(P<0.05)$ molar proportion of acetate than the control diet throughout the sampling period. At $6 \mathrm{~h}$ postprandial, the KHLL goats had a significantly lower $(P<0.05)$ ammonia nitrogen than the goats fed other diets. The molar proportion of propionate ( 24.7 and $25.8 \mathrm{~mol} / 100 \mathrm{~mol}$ ) was greater in the rumen of KHLL goats compared with those fed other diets at 2 and $12 \mathrm{~h}$ postprandial, respectively. The KHLL diet had lower $(P<0.05)$ butyrate than other dietary treatments. At $4 \mathrm{~h}$ postprandial, the control goats had a lower $(P<0.05)$ population of total bacteria while the KHLL goats had a greater $(P<0.05)$ population at 4 and $12 \mathrm{~h}$ postprandial compared with those fed other diets. The LL, KH, and KHLL goats had lower $(P<0.05)$ populations of protozoa and methanogens and a greater $(P<0.05)$ population of Ruminococcus albus
\end{abstract}

Anjas Asmara Samsudin

anjas@upm.edu.my

1 Department of Animal Science, Faculty of Agriculture, Universiti Putra Malaysia, UPM, 43400 Serdang, Selangor Darul Ehsan, Malaysia

2 Animal Production Laboratory, Institute of Tropical Agriculture, Universiti Putra Malaysia, Serdang, Selangor, Malaysia compared with the control goats. The KHLL leaves could be fed to goats without compromising rumen metabolism.

Keywords Kleinhovia hospita Leucaena leucocephala . Microbial population $\cdot$ Rumen fermentation

\section{Introduction}

One of the major constraints to sustainable ruminant production particularly in the tropics is the lack of affordable and available feed resources (Devendra and Leng 2011). This is due to the high cost of conventional feedstuffs and the competition between man and livestock industry for the available conventional feedstuffs (Leng 2008). Thus, the use of cheaper feed alternatives with high proximity and year-round availability has been the subject of research in recent years.

Various tree forages have been used as supplement of protein source in the diets of ruminants. Nonetheless, the presence of plant secondary metabolites in the tree forages could limit their nutritional value (Kim et al. 2015). In addition, the effects of tree forages on rumen metabolism and growth performance in ruminants have been highly inconsistent and variable in the published literature. This development has stimulated the interest for additional studies in different production systems to permit tailored decisions and informed choices in the utilization of tree forages in ruminant nutrition.

To the best of our knowledge, the efficacy of Kleinhovia hospita as ruminant feed has not been investigated. Therefore, the objective of this study was to determine the effect of feeding $K$. hospita $(\mathrm{KH})$, Leucaena 
leucocephala (LL), and $K$. hospita mixed with L. leucocephala (KHLL) on rumen fermentation profile and microbial population in goats fed with urea-treated rice straw.

\section{Materials and methods}

\section{Animal welfare and ethics}

This study was carried out following the guidelines of the research policy of the Universiti Putra Malaysia (UPM) on animal welfare and ethics. The care of the experimental goats was in accordance with Malaysian standards.

\section{Experimental animals and feeding}

The experiment was carried out at Field 2 (longitude $101^{\circ} 42^{\prime} 09.4^{\prime \prime} \mathrm{E}$ and latitude $3^{\circ} 00^{\prime} 27.7^{\prime \prime} \mathrm{N}$ ) Ruminant Farm, Department of Animal Science, Faculty of Agriculture, UPM. Four crossbred Boer bucks weighing $30-32 \mathrm{~kg}$ and fitted with permanent ruminal cannulas were used in a $4 \times 4$ Latin square design. Each goat was housed separately and fed $60 \%$ treated rice straw (basal diet) and $40 \%$ dietary treatment based on $3 \%$ body weight. The dietary treatments were T1: concentrate supplement (control), T2: K. hospita leaves, T3: L. leucocephala, and T4: mixture of K. hospita and L. leucocephala. The soybean meal and palm kernel cake were partially or wholly replaced by the forages. The adaptation period was 2 weeks prior to the commencement of the experiment and the goats were fed once a day $(0800 \mathrm{~h})$. A 5 -day interval of non-treatment diet was allowed to avoid residual effect of the dietary treatments. The goats had ad libitum access to water throughout the trial. The rumen samples were collected at $0,2,4,6$, and $12 \mathrm{~h}$ postprandial. The $\mathrm{pH}$ of the rumen fluid was measured immediately after collection using a $\mathrm{pH}$ meter (Mettler-Toledo Ltd., England). The samples were squeezed through four layers of cheesecloth and frozen $\left(-20^{\circ} \mathrm{C}\right)$ until further analysis.

\section{Feed analysis}

The proximate compositions of the treatments were presented in Table 1 and determined according to the protocol of AOAC (2007) while the detergent fibers were determined according to the method of Van Soest et al. (1991). The gross energy content of the treatments was determined using adiabatic bomb calorimeter (Leco Corporation, MI 49085, USA). Estimation of total polyphenol and tannins was done following the procedure of Makkar et al. (1993).

\section{Estimation of rumen fermentation parameters}

The determination of the VFA concentration and molar proportions were achieved by gas chromatography (Agilent $69890 \mathrm{~N}$ Series) fitted with a flame ionization detector. About three to five drops of $10 \% \mathrm{H}_{2} \mathrm{SO}_{4}$ was added to $5 \mathrm{~mL}$ of rumen fluid and kept at $-20{ }^{\circ} \mathrm{C}$ until further analysis Cottyn and Boucque 1968 using $0.5 \mathrm{~mL}$ of $20 \mathrm{mmol} / \mathrm{L} 4$ methyl- $n$-valeric acid as the internal standard. The $\mathrm{NH}_{3}-\mathrm{N}$ concentration of the rumen fluid was evaluated as described by Parsons et al. (1984). The absorbance was determined at $640 \mathrm{~nm}$ using a Spectro SC spectrophotometer (Labomed Inc., Culver City, CA).

\section{Microbial quantification}

\section{Rumen microbial DNA extraction}

The extraction of DNA in rumen fluid DNA was determined by using the cetyltrimethylammonium bromide (CTAB) extraction procedure as described by Samsudin et al. (2011). The extracted DNA pellet was resuspended in $50 \mu \mathrm{LTE}$ and stored at $-20{ }^{\circ} \mathrm{C}$ until further analysis. BioPhotometer plus (Eppendorf W/Hellma Traycell 952000070) was used to determine the extracted DNA concentration.

\section{Quantitative real-time PCR}

Species-specific quantitative real-time PCR was carried out using CFX96 Touch Real-Time PCR Detection System (BioRad, USA) with an optical grade plate of SYBR Green mix detection. The reaction of the PCR was executed on a total volume of $25 \mu \mathrm{L}$ using QuantiFast SYBR® Green RT-PCR Kit. The reaction of each sample was made up of $12.5 \mu \mathrm{L}$ SYBR Green Supermix, $1 \mu \mathrm{L}$ of forward primer, $1 \mu \mathrm{L}$ of reverse primer, $2 \mu \mathrm{L}$ of DNA samples, and $9.5 \mu \mathrm{L}$ DNA template and RNAse free water. The mixed samples were placed in Axygen scientific 0.2 RT PCR strips. The PCR reaction conditions applied to each well was as follows: 5-min initial incubation at $94{ }^{\circ} \mathrm{C}$ then 40 cycles at $94{ }^{\circ} \mathrm{C}$ for $20 \mathrm{~s}$ for denaturation followed by annealing temperature (depending on the primers) (Table 2) for $30 \mathrm{~s}$, and extended to $72{ }^{\circ} \mathrm{C}$ for $20 \mathrm{~s}$ (Jahromi et al. 2013).

Primers used to quantify the population of different groups of microorganisms are shown in Table 2. The number of copies of a template DNA per milliliter of elution buffer was quantified using the formula that is available online. (http:// www.uri.edu/research/gsc/resources/cndna.htmL):

Number of copies $=\frac{\text { Amount of } \mathrm{DNA}(\mu \mathrm{g} / \mathrm{mL}) \times 6.022 \times 10^{23}}{\text { Length of }(\mathrm{bp}) \times 10^{9} \times 650} \times 100$ 
Table 1 Chemical composition of the experimental diets

\begin{tabular}{|c|c|c|c|c|c|}
\hline Ingredients (\%) & $\mathrm{CD}$ & $\mathrm{KH}$ & LL & KHLL & RS \\
\hline Treated rice straw (\%) from the total ration & 60.00 & 60.00 & 60.00 & 60.00 & \\
\hline Corn & 19.30 & 19.30 & 19.30 & 19.30 & \\
\hline Palm kernel cake & 57.80 & 15.30 & 27.30 & - & \\
\hline Soybean meal & 20.90 & 13.50 & 13.50 & - & \\
\hline $\mathrm{KH}$ & - & 50.00 & - & 20.00 & \\
\hline LL & - & - & 38.00 & 58.74 & \\
\hline $\mathrm{CaCO}_{3}$ & 0.50 & 0.50 & 0.50 & 0.50 & \\
\hline $\mathrm{NaCl}$ & 0.50 & 0.50 & 0.50 & 0.50 & \\
\hline Min. premix & 1.00 & 1.00 & 1.00 & 1.00 & \\
\hline \multicolumn{6}{|l|}{ Chemical composition \% DM } \\
\hline Dry matter & 90.50 & 91.00 & 90.40 & 92.00 & 96.60 \\
\hline Ash & 6.08 & 7.01 & 6.90 & 7.84 & 12.90 \\
\hline Organic matter & 93.90 & 93.00 & 93.00 & 92.20 & 87.10 \\
\hline Crude protein & 20.00 & 19.80 & 19.90 & 19.70 & 5.00 \\
\hline Ether extract & 1.39 & 2.39 & 1.48 & 3.00 & 1.63 \\
\hline Crude fiber & 9.61 & 10.30 & 13.00 & 13.70 & 36.30 \\
\hline Neutral detergent fiber & 49.60 & 50.80 & 43.50 & 39.20 & 80.80 \\
\hline Acid detergent fiber & 19.40 & 18.80 & 18.60 & 19.40 & 48.60 \\
\hline Lignin & 8.00 & 10.50 & 13.00 & 13.30 & 31.60 \\
\hline Gross energy $\mathrm{MJ} / \mathrm{kgDM}$ & 14.50 & 15.40 & 15.50 & 15.90 & 14.80 \\
\hline Tannin $(\%)$ & - & 1.26 & 0.95 & 1.39 & - \\
\hline
\end{tabular}

CD (control diet), KH (Kleinhovia hospita diet), LL (Leucaena leucocephala diet), KHLL (Kleinhovia hospita and Leucaena leucocephala mixed diet), RS (rice straw)

The amplification efficiency was estimated using the equation $E=\left(10^{-1 / \text { slope }}-1\right) \times 100 \%$.

\section{Statistical analysis}

Data obtained for all variables were analyzed using the MIXED procedure of SAS (2012). Diet, time, and interaction between diet and time were fitted as a fixed effect in a repeated measure analysis. Differences between means were separated by the Duncan multiple range test at $P<0.05$.

\section{Results and discussion}

\section{Rumen fermentation profile}

\section{Rumen $\mathrm{pH}$}

The mean ruminal $\mathrm{pH}$ of goats fed different dietary supplements is presented in Table 3. The mean $\mathrm{pH}$ ranged from 6.16 to 7.05 and was within the range for normal $\mathrm{pH}$ for optimum rumen metabolism (Valente et al. 2016). Dietary treatments and sampling time had significant effects $(P<0.05)$ on rumen $\mathrm{pH}$ in goats. The $\mathrm{pH}$ value decreased over sampling time. This observation suggests an increase in the rumen fermentation of the dietary treatments. The KHLL diet had a greater $\mathrm{pH}$ than the control diet throughout the sampling period perhaps due to the presence of polyphenol (Kim et al. 2015). A similar trend was observed for $\mathrm{KH}$ and $\mathrm{LL}$ diets though the results were inconsistent. The lower rumen $\mathrm{pH}$ in the KHLL goats could be due to the lower total VFA (Table 4) induced by the greater amount of polyphenols (\% tannin) in the diets (Table 1). Changes in rumen $\mathrm{pH}$ of goats fed a different diet with respect to sampling time are an indication of varying buffering capacity and degradation of feed in the rumen (Castillo-González et al. 2014). 
Table 2 Primers for real-time PCR assay (Jahromi et al. 2013)

\begin{tabular}{|c|c|c|c|}
\hline Target group & Sequence $5^{\prime}-3^{\prime}$ & Product size (bp) & Annealing temperature $\left({ }^{\circ} \mathrm{C}\right)$ \\
\hline Total bacteria F & CGGCAACGAGCGCAACCC & 145 & 55 \\
\hline Total bacteria $\mathrm{R}$ & CCATTGTAGCACGTGTGTAGCC & & \\
\hline Methanogens (mcrA)-F & TTCGGTGGATCDCARAGRGC & 140 & 58 \\
\hline Methanogens (mcrA)-R & GBARGTCGWAWCCGTAGAATCC & & \\
\hline Ruminococcus albus $\mathrm{F}$ & CCCTAAAAGCAGTCTTAGTTCG & 175 & 55 \\
\hline Ruminococcus albus $\mathrm{R}$ & CCTCCTTGCGGTTAGAACA & & \\
\hline Ruminococcus flavefaciens $\mathrm{F}$ & TCTGGAAACGGATGGTA & 259 & 60 \\
\hline Ruminococcus flavefaciens $\mathrm{R}$ & CCTTTAAGACAGGAGTTTACAA & & \\
\hline Fibrobacter succinogenes $\mathrm{F}$ & GTTCGGAATTACTGGGCGTAAA & 122 & 55 \\
\hline Fibrobacter succinogenes $\mathrm{R}$ & CGCCTGCCCCTGAACTATC & & \\
\hline Protozoa F & CTTGCCCTCYAATCGTWCT & 223 & 55 \\
\hline Protozoa R & GCTTTCGWTGGTAGTGTATT & & \\
\hline
\end{tabular}

\section{Rumen ammonia $N$}

Ammonia nitrogen serves as an effective indicator of protein degradation in the rumen and it is the major source of microbial protein synthesis in the rumen (Adeyemi et al. 2016). The concentration of ruminal ammonia nitrogen in goats as influenced by dietary treatments and sampling time is presented in Table 3. Sampling time had a significant impact $(P<0.05)$ on the concentration of ammonia nitrogen in goats. Regardless of the dietary treatment, the concentration of ammonia nitrogen increased from 0 to $4 \mathrm{~h}$ postprandial and declined afterwards. This implies that at $4 \mathrm{~h}$ postprandial, the proteolytic activities of the microflora were optimum.

The range and trend of ammonia concentration over time are in tandem with the findings of Yanez-Ruiz et al. (2004). However, at $6 \mathrm{~h}$ postprandial, the KHLL goats had a significantly lower $(P<0.05)$ ammonia nitrogen than goats fed other diets. This observation could be attributed to the presence of greater amount of phenolic compound (tannin) in the KHLL diet compared with other diets. The reduction in the ruminal degradation of protein associated with the reduction in ruminal ammonia nitrogen is the most common effect of phenolic compounds (Pitta et al. 2010). The low rumen ammonia-N concentration in KHLL goats could be due to reduced

Table 3 Mean ruminal $\mathrm{pH}$ and ammonia nitrogen in goats as influenced by dietary treatments and sampling time

\begin{tabular}{|c|c|c|c|c|c|c|c|c|c|}
\hline \multirow[t]{2}{*}{ Parameter } & \multicolumn{6}{|l|}{ Time (h) } & \multirow[t]{2}{*}{ SEM } & \multirow[t]{2}{*}{$P$ value } & \multirow[t]{2}{*}{ DXT } \\
\hline & Diet & 0 & 2 & 4 & 6 & 12 & & & \\
\hline \multirow[t]{5}{*}{$\mathrm{pH}$} & $\mathrm{CD}$ & $6.79^{\mathrm{bw}}$ & $6.69^{\mathrm{cw}}$ & $6.61^{\mathrm{cwx}}$ & $6.47^{\mathrm{cy}}$ & $6.16^{\mathrm{cy}}$ & 0.238 & 0.0001 & \multirow{5}{*}{0.0012} \\
\hline & $\mathrm{KH}$ & $6.95^{\text {abw }}$ & $6.81^{\mathrm{bx}}$ & $6.69^{\text {bcy }}$ & $6.60^{\text {by }}$ & $6.33^{\mathrm{bcz}}$ & 0.236 & $<0.0001$ & \\
\hline & LL & $6.93^{\text {abw }}$ & $6.81^{\text {bwx }}$ & $6.75^{\mathrm{abx}}$ & $6.58^{\text {bcy }}$ & $6.41^{\mathrm{bz}}$ & 0.203 & $<0.0001$ & \\
\hline & KHLL & $7.05^{\text {aw }}$ & $6.90^{\mathrm{ax}}$ & $6.86^{\mathrm{ax}}$ & $6.75^{\mathrm{ay}}$ & $6.67^{\mathrm{az}}$ & 0.145 & $<0.0001$ & \\
\hline & $P$ value & 0.036 & 0.002 & 0.008 & 0.006 & 0.0008 & & & \\
\hline \multirow[t]{5}{*}{ Ammonia nitrogen $(\%)$} & $\mathrm{CD}$ & $12.10^{\mathrm{x}}$ & $21.60^{\mathrm{wx}}$ & $23.30^{\text {aw }}$ & $15.60^{\mathrm{wx}}$ & $0.95^{\mathrm{y}}$ & 8.93 & 0.0100 & \multirow{5}{*}{0.214} \\
\hline & $\mathrm{KH}$ & $7.38^{\mathrm{y}}$ & $14.90^{\mathrm{x}}$ & $21.80^{\mathrm{aw}}$ & $11.70^{\mathrm{xy}}$ & $0.72^{\mathrm{z}}$ & 8.15 & 0.0007 & \\
\hline & LL & $6.55^{\mathrm{y}}$ & $14.90^{\mathrm{x}}$ & $22.60^{\text {aw }}$ & $14.30^{\mathrm{x}}$ & $0.85^{\mathrm{z}}$ & 8.36 & 0.0005 & \\
\hline & KHLL & $4.25^{\mathrm{y}}$ & $12.90^{\mathrm{x}}$ & $18.20^{\mathrm{bw}}$ & $12.50^{\mathrm{x}}$ & $0.31^{z}$ & 7.61 & $<0.0001$ & \\
\hline & $P$ value & 0.101 & 0.075 & 0.011 & 0.683 & 0.055 & & & \\
\hline
\end{tabular}

CD (control diet), KH (Kleinhovia hospita diet), LL (Leucaena leucocephala diet), KHLL (Kleinhovia hospita and Leucaena leucocephala mixed diet), SEM (standard error of mean), DXT (diet-time interaction for all the treatments)

${ }^{\text {abcd }}$ Means with different superscripts along the same column are significantly different $(P<0.05)$

${ }^{\text {wxyz }}$ Means with different superscripts along the row are significantly different $(\mathrm{P}<0.05)$ 
Table 4 Total and molar proportions of volatile fatty acids in the rumen of goats as influenced by dietary treatments and sampling time

\begin{tabular}{|c|c|c|c|c|c|c|c|c|c|}
\hline & \multicolumn{6}{|l|}{ Time (h) } & \multicolumn{3}{|c|}{ SEM $P$ value DXT } \\
\hline & Diet & 0 & 2 & 4 & 6 & 12 & & & \\
\hline \multirow[t]{5}{*}{ Total VFA (mM) } & $\mathrm{CD}$ & 93.8 & $104^{\mathrm{b}}$ & $80.5^{\mathrm{b}}$ & 83.7 & 104 & 11.0 & 0.07 & \\
\hline & $\mathrm{KH}$ & $91.2^{\mathrm{x}}$ & $88.0^{\mathrm{dx}}$ & $86.3^{\mathrm{bx}}$ & $89.9^{\mathrm{x}}$ & $111^{\mathrm{w}}$ & 10.2 & 0.05 & \\
\hline & LL & 100.0 & $111.0^{\mathrm{a}}$ & $104.0^{\mathrm{a}}$ & 104.0 & 99.6 & 4.28 & 0.7 & 0.09 \\
\hline & KHLL & $86.4^{x y}$ & $95.8^{\mathrm{cwx}}$ & $79.4^{\mathrm{cy}}$ & $87.9^{x y}$ & $103^{\mathrm{w}}$ & 9.25 & 0.04 & \\
\hline & $P$ value & 0.57 & 0.002 & 0.02 & 0.1 & 0.63 & & & \\
\hline \multirow[t]{5}{*}{ Acetate $(\mathrm{mol} / 100 \mathrm{~mol})$} & $\mathrm{CD}$ & $55.7^{\mathrm{b}}$ & $55.3^{\mathrm{b}}$ & $53.7^{\mathrm{b}}$ & $54.1^{\mathrm{c}}$ & $53.7^{\mathrm{b}}$ & 0.96 & 0.29 & \\
\hline & $\mathrm{KH}$ & $56.5^{\mathrm{b}}$ & $57.1^{\mathrm{b}}$ & $58.3^{\mathrm{a}}$ & $56.4^{\mathrm{b}}$ & $56.5^{\mathrm{ab}}$ & 0.8 & 0.16 & \\
\hline & LL & $54.4^{\mathrm{b}}$ & $57.4^{\mathrm{b}}$ & $57.5^{\mathrm{ab}}$ & $56.7^{\mathrm{b}}$ & $53.8^{\mathrm{b}}$ & 1.74 & 0.23 & 0.2071 \\
\hline & KHLL & $60.1^{\mathrm{a}}$ & $60.5^{\mathrm{a}}$ & $61.2^{\mathrm{a}}$ & $60.7^{\mathrm{a}}$ & $59.7^{\mathrm{a}}$ & 0.56 & 0.8 & \\
\hline & $P$ value & 0.02 & 0.04 & 0.05 & 0.004 & 0.03 & & & \\
\hline \multirow[t]{5}{*}{ Propionate $(\mathrm{mol} / 100 \mathrm{~mol})$} & $\mathrm{CD}$ & $20.2^{\mathrm{x}}$ & $23.4^{\mathrm{bw}}$ & $22.7^{\mathrm{w}}$ & $22.6^{\mathrm{w}}$ & $22.8^{\mathrm{bw}}$ & 1.38 & 0.002 & \\
\hline & KH & 20.9 & $21.8^{\mathrm{c}}$ & 22.0 & 22.3 & $23.9^{\mathrm{b}}$ & 0.61 & 0.17 & \\
\hline & LL & 20.6 & $23.4^{\mathrm{b}}$ & 23.1 & 22.5 & $23.8^{\mathrm{b}}$ & 1.11 & 0.25 & 0.14 \\
\hline & KHLL & $22.3^{\mathrm{x}}$ & $24.7^{\mathrm{awx}}$ & $23.9^{\mathrm{wx}}$ & $24.1^{\mathrm{wx}}$ & $25.8^{\mathrm{aw}}$ & 1.28 & 0.04 & \\
\hline & $P$ value & 0.32 & 0.01 & 0.19 & 0.14 & 0.01 & & & \\
\hline \multirow[t]{5}{*}{ Butyrate (mol/100 mol) } & $\mathrm{CD}$ & $14.2^{\mathrm{y}}$ & $14.1^{\text {by }}$ & $15.9^{\mathrm{ax}}$ & $16.7^{\mathrm{bwx}}$ & $18.3^{\text {aw }}$ & 1.78 & 0.01 & \\
\hline & $\mathrm{KH}$ & $15.2^{\mathrm{z}}$ & $15.9^{\mathrm{ayz}}$ & $16.9^{\text {axy }}$ & $17.9^{\text {awx }}$ & $18.6^{\mathrm{aw}}$ & 1.41 & 0.01 & \\
\hline & LL & $16.9^{\mathrm{wx}}$ & $13.1^{\text {by }}$ & $14.6^{\text {axy }}$ & $16.2^{\text {bwxy }}$ & $18.9^{\mathrm{aw}}$ & 2.23 & 0.04 & 0.002 \\
\hline & KHLL & $12.7^{\mathrm{wx}}$ & $10.7^{\mathrm{cy}}$ & $11.9^{\mathrm{bx}}$ & $13.3^{\mathrm{cw}}$ & $13.4^{\mathrm{bw}}$ & 1.12 & 0.002 & \\
\hline & $P$ value & 0.12 & 0.002 & 0.02 & 0.0002 & 0.005 & & & \\
\hline
\end{tabular}

CD (control diet), KH (Kleinhovia hospita diet), LL (Leucaena leucocephala diet), KHLL (Kleinhovia hospita and Leucaena leucocephala mixed diet), SEM (standard error of mean), DXT (diet time interaction for all the treatments)

${ }^{\text {abcd }}$ Means with different superscripts along the same column are significantly different $(P<0.05)$

${ }^{\text {wxyz }}$ Means with different superscripts along the row are significantly different $(P<0.05)$

recycling of bacterial protein owing to a lower protozoa population (Abubakr et al. 2013).

\section{Total and molar proportions of VFA}

The total and molar proportions of VFA in the rumen of goats fed different dietary treatments are presented in Table 4. Dietary treatments had no effect $(P>0.05)$ on the concentration of ruminal total VFA in goats at 0,6 , and $12 \mathrm{~h}$ postprandial. At 4 and $6 \mathrm{~h}$ postprandial, the total VFA varied among the treatments. This observation could be due to the variation in the concentration, types, and sources of tannin in the diets. Sampling time influenced the concentration of total VFA in KHLL and KH goats but the changes were inconsistent. Similar inconsistencies in total VFA were observed in goats fed leaf meal-based diets (Singh et al. 2011).

Dietary treatments had a significant impact on the molar proportion of acetate in the rumen of goats. The KHLL goats had greater $(P<0.05)$ concentrations of acetate than the control goats throughout the sampling period. The molar proportion of acetate did not differ between the control goats and those fed the LL and $\mathrm{KH}$ diets at $0,2,4$, and $12 \mathrm{~h}$ postprandial. Sampling time did not affect $(P>0.05)$ the molar proportion of acetate in goats. The greater acetate in the rumen of KHLL goats could be due to the higher cellulose content in the diets resulting to greater feed degradation. The presence of acetate in ruminant is essential as it increases colonic blood flow and enhances ileal motility and milk fat formation (Scheppach 1994). The molar proportion of propionate was greater $(P<0.05)$ in the rumen of KHLL goats compared with those fed other diets at 2 and $12 \mathrm{~h}$ postprandial. The higher proportion of propionate shows better utilization of the dietary energy since the formation of propionate reduces the amount of hydrogen gas available for the synthesis of methane. The KHLL diet had lower $(P<0.05)$ butyrate than other dietary treatments. This observation could be attributed to the reduced population of protozoa in the rumen of KHLL goats. A decrease in butyrate and an increase in propionate often characterize the absence of protozoa (Kara et al. 2017). The current observation is consistent with the findings of Franzolin et al. (2010) who observed a lower butyrate concentration in the rumen of cattle and buffalo fed citrus pulp and soybean meal. 
Table 5 Rumen microflora $\left(\log _{10}\right.$ copy no/mL) in goats as influenced by dietary treatments and sampling time

\begin{tabular}{|c|c|c|c|c|c|c|c|}
\hline & \multirow[t]{2}{*}{ Diet } & \multicolumn{3}{|c|}{ Time (h) } & \multirow[t]{2}{*}{ SEM } & \multirow[t]{2}{*}{$P$ value } & \multirow[t]{2}{*}{ DXT } \\
\hline & & 0 & 4 & 12 & & & \\
\hline \multirow[t]{5}{*}{ Total bacteria } & $\mathrm{CD}$ & $9.37^{\mathrm{x}}$ & $5.49^{\mathrm{cz}}$ & $8.77^{\text {by }}$ & 2.090 & 0.0002 & 0.0371 \\
\hline & $\mathrm{KH}$ & $9.02^{\mathrm{x}}$ & $8.84^{b x}$ & $8.42^{\mathrm{cy}}$ & 0.308 & 0.0069 & \\
\hline & LL & $9.09^{\mathrm{y}}$ & $10.21^{\mathrm{ax}}$ & $8.77^{\text {by }}$ & 0.755 & 0.0026 & \\
\hline & KHLL & 9.33 & $9.52^{\mathrm{ab}}$ & $9.23^{\mathrm{a}}$ & 0.150 & 0.8550 & \\
\hline & $P$ value & 0.72 & 0.0004 & 0.0016 & & & \\
\hline \multirow[t]{5}{*}{ Total protozoa } & $\mathrm{CD}$ & $3.98^{\mathrm{y}}$ & $6.94^{\mathrm{ax}}$ & $3.39^{\mathrm{y}}$ & 1.900 & 0.010 & \\
\hline & $\mathrm{KH}$ & $4.27^{\mathrm{x}}$ & $3.40^{\mathrm{bxy}}$ & $3.30^{\mathrm{y}}$ & 0.534 & 0.055 & 0.021 \\
\hline & LL & 4.02 & $4.15^{\mathrm{ab}}$ & 3.37 & 1.450 & 0.188 & \\
\hline & KHLL & $3.72^{x y}$ & $4.00^{\mathrm{abx}}$ & $2.83^{\mathrm{y}}$ & 0.623 & 0.054 & \\
\hline & $P$ value & 0.433 & 0.052 & 0.453 & & & \\
\hline \multirow[t]{5}{*}{ Methanogen archaea } & $\mathrm{CD}$ & $6.94^{\mathrm{y}}$ & $8.39^{\mathrm{ax}}$ & $7.01^{\text {ay }}$ & 0.820 & 0.010 & 0.001 \\
\hline & KH & 6.92 & $6.70^{\mathrm{c}}$ & $6.39^{\mathrm{b}}$ & 0.930 & 0.586 & \\
\hline & LL & 6.79 & $7.47^{\mathrm{b}}$ & $7.00^{\mathrm{a}}$ & 0.344 & 0.173 & \\
\hline & KHLL & $6.79^{\mathrm{x}}$ & $6.49^{\mathrm{cx}}$ & $6.00^{\text {by }}$ & 0.396 & 0.011 & \\
\hline & $P$ value & 0.906 & 0.002 & 0.014 & & & \\
\hline \multirow[t]{5}{*}{ Ruminococcus albus } & $\mathrm{CD}$ & $6.19^{\mathrm{x}}$ & $3.33^{\text {by }}$ & $5.44^{\mathrm{cx}}$ & 1.480 & 0.035 & 0.0037 \\
\hline & $\mathrm{KH}$ & $5.39^{\mathrm{y}}$ & $5.19^{\mathrm{ay}}$ & $6.02^{\mathrm{bx}}$ & 0.432 & 0.024 & \\
\hline & LL & 5.82 & $5.95^{\mathrm{a}}$ & $6.33^{\mathrm{a}}$ & 0.267 & 0.191 & \\
\hline & KHLL & 6.02 & $6.05^{\mathrm{a}}$ & $6.29^{\mathrm{a}}$ & 0.146 & 0.328 & \\
\hline & $P$ value & 0.061 & 0.021 & 0.0017 & & & \\
\hline \multirow[t]{5}{*}{ R. flavefaciens } & $\mathrm{CD}$ & $6.64^{\mathrm{ax}}$ & $4.22^{\mathrm{dz}}$ & $5.82^{\text {aby }}$ & 1.720 & $<0.0001$ & $<0.0001$ \\
\hline & $\mathrm{KH}$ & $6.60^{\mathrm{ax}}$ & $6.54^{\mathrm{cx}}$ & $6.05^{\text {ay }}$ & 0.301 & 0.0022 & \\
\hline & LL & $5.74^{\text {by }}$ & $7.16^{\mathrm{ax}}$ & $5.27^{\mathrm{cz}}$ & 0.980 & 0.0008 & \\
\hline & KHLL & $5.88^{\text {by }}$ & $6.85^{\mathrm{bx}}$ & $5.48^{\text {bcy }}$ & 0.706 & 0.0094 & \\
\hline & $P$ value & 0.0005 & $<0.0001$ & 0.0311 & & & \\
\hline \multirow[t]{5}{*}{ Fibrobacter succinogenes } & $\mathrm{CD}$ & 5.61 & 5.21 & 4.96 & 0.324 & 0.1410 & 0.13 \\
\hline & $\mathrm{KH}$ & $5.89^{\mathrm{x}}$ & $5.19^{\mathrm{xy}}$ & $5.02^{\mathrm{y}}$ & 0.459 & 0.0712 & \\
\hline & LL & $5.28^{\mathrm{xy}}$ & $5.69^{\mathrm{x}}$ & $4.84^{\text {by }}$ & 0.429 & 0.0238 & \\
\hline & KHLL & 5.88 & 5.71 & 5.63 & 0.129 & 0.8660 & \\
\hline & $P$ value & 0.082 & 0.485 & 0.112 & & & \\
\hline
\end{tabular}

CD (control diet), KH (Kleinhovia hospita diet), LL (Leucaena leucocephala diet), KHLL (Kleinhovia hospita and Leucaena leucocephala mixed diet), SEM (standard error of mean), DXT (diet time interaction for all the treatments)

${ }^{\text {abcd }}$ Means with different superscripts along the same column are significantly different $(P<0.05)$

${ }^{\text {wxyz }}$ Means with different superscripts along the row are significantly different $(P<0.05)$

\section{Rumen microbial profile}

\section{Total bacteria}

The rumen microbiota in goats fed different dietary treatments and sampled over different postprandial periods is shown in Table 5. Dietary treatments had no effect $(P<0.05)$ on the population of total rumen bacteria in goats at $0 \mathrm{~h}$ postprandial. A similar finding was observed in goats fed pakar leaves and green oats (Singh et al. 2011). At 4 h postprandial, the control goats had a lower $(P<0.05)$ population of total bacteria while the KHLL goats had greater $(P<0.05)$ populations at 4 and
$12 \mathrm{~h}$ postprandial compared with those fed other diets. The greater total bacteria in goats fed tree forages could be attributed to the lower population of protozoa, which caused less engulfment of the bacteria. Postprandial sampling time influenced the population of total bacteria in goats fed the control, $\mathrm{LL}$, and $\mathrm{KH}$ diets. However, the changes were inconsistent.

\section{Protozoa}

The total protozoa population in the rumen of goats was not influenced by dietary treatments at 0 and $12 \mathrm{~h}$ postprandial. However, at $4 \mathrm{~h}$ postprandial, the control goats had greater 
$(P<0.05)$ population of total protozoa compared with those fed tree forages. The presence of tannin in the tree forages could be responsible for the decrease in the population of protozoa. This observation is consistent with the finding of Singh et al. (2011) who reported a reduction in the rumen protozoa count in cows and buffalos fed pakar leaves compared to oat leaves. In contrast, Benchaar et al. (2008) did not observe significant differences in protozoa numbers in dairy cattle fed quebracho tannins (CT concentrations of $700 \mathrm{~g} / \mathrm{kg}, 150 \mathrm{~g} /$ day).

\section{Methanogens archaea}

Goats fed tree forages had lower $(P<0.05)$ population of methanogens at 4 and $12 \mathrm{~h}$ postprandial. This observation could be attributed to the reduced population of protozoa in the goats caused by the presence of tannin in the diets. Similarly, tannin reduced the population of methanogens (Kim et al. 2015). Contrary to the present observation, supplementation of pakar leaves increased the population of methanogens in goats (Singh et al. 2011).

\section{Cellulolytic bacteria}

Dietary supplementation of tree forages influenced the populations of $R$. albus and $R$. flavefaciens but did not affect the population of Fibrobacter succinogenes in the rumen of goats. Goats fed LL, KH, and KHLL diets had a greater $(P<0.05)$ population of $R$. albus than the control goats at 4 and $12 \mathrm{~h}$ postprandial. The response of $R$. flavefaciens to dietary tree forages was inconsistent. The increase in the population of $R$. albus in the rumen of goats supplemented with tree forages could be due to the reduced population of protozoa or the high-fiber content of the diets. Similarly, high forage diet increased the population of cellulolytic bacteria in beef cattle (Carberry et al. 2012).

\section{Conclusion}

The results of the present study showed that the supplementation $K$. hospita, L. leucocephala, and their mix could be used in the diet of goats fed urea-treated rice straw without compromising rumen metabolism and microbial population.

Compliance with ethical standards This study was carried out following the guidelines of the research policy of the Universiti Putra Malaysia (UPM) on Animal welfare and ethics. The care of the experimental goats was in accordance with Malaysian standards.

Conflict of interest The authors declare that they have no conflict of interest.
Open Access This article is distributed under the terms of the Creative Commons Attribution 4.0 International License (http:// creativecommons.org/licenses/by/4.0/), which permits unrestricted use, distribution, and reproduction in any medium, provided you give appropriate credit to the original author(s) and the source, provide a link to the Creative Commons license, and indicate if changes were made.

\section{References}

Abubakr, A.R., Alimon, A.R., Yaakub, H., Abdullah, N. and Ivan, M., 2013. Digestibility, rumen protozoa, and ruminal fermentation in goats receiving dietary palm oil by-products, Journal of the Saudi Society of Agricultural Sciences, 12(2), 147-154.

Adeyemi, K.D., Ahmed, M.A., Jotham, S., Roslan, N.A, Jahromi, M.F., Samsudin, A.A. and Sazili, A.Q., 2016. Rumen microbial community and nitrogen metabolism in goats fed blend of palm oil and canola oil, Italian Journal of Animal Science, 15(4), 666-672.

AOAC 2007. Official Methods of Analysis. Gaithersburg: Association of Official Analytical Chemists.

Benchaar, C., McAllister, T.A. and Chouinard, P.Y., 2008. Digestion, ruminal fermentation, ciliate protozoal populations, and milk production from dairy cows fed cinnamaldehyde, quebracho condensed tannin, or Yucca schidigera saponin extracts, Journal of Dairy Science, 91(12), 4765-4777.

Carberry, C.A., Kenny, D.A., Han, S, McCabe, M.S. and Waters, S.M., 2012. Effect of phenotypic residual feed intake and dietary forage content on the rumen microbial community of beef cattle, Applied and Environmental Microbiology, 78(14), 4949-4958.

Castillo-González, A.R., Burrola-Barraza, M.E., Domínguez-Viveros, J. and Chávez-Martínez, A., 2014. Microorganismos y fermentación ruminal, Archivos de Medicina Veterinaria, 46(3), 349-361.

Cottyn, B.G. and Boucque, C.V., 1968. Rapid method for the gaschromatographic determination of volatile fatty acids in rumen fluid, Journal of Agricultural and Food Chemistry, 16(1), 105-107.

Devendra, C. and Leng R.A., 2011. Feed resources for animals in Asia: Issues, strategies for use, intensification and integration for increased productivity, Asian-Australasian Journal of Animal Sciences, 24, 303-321.

Jahromi, M.F., Liang, J.B., Mohamad, R., Goh, Y.M., Shokryazdan, P. and Ho, Y.W., 2013. Lovastatin-enriched rice straw enhances biomass quality and suppresses ruminal methanogenesis, BioMed research international, http://www.hindawi.com/journals/bmri/2013/ 397934/abs/

Franzolin, R., Rosales, F.P. and Soares, W.V.B., 2010. Effects of dietary energy and nitrogen supplements on rumen fermentation and protozoa population in buffalo and zebu cattle, Revista Brasileira de Zootecnia, 39(3), 549-555.

Kara, K., Özkaya, S., Erbaş, S. and Baytok, E., 2017. Effect of dietary formic acid on the in vitro ruminal fermentation parameters of barley-based concentrated mix feed of beef cattle, Journal of Applied Animal Research, 1-6.

Kim, E.T., Le Luo Guan, S.J.L., Lee, S.M., Lee, S. S., Lee, I.D., Lee, S.K. and Lee, S.S., 2015. Effects of flavonoid-rich plant extracts on in vitro ruminal methanogenesis, microbial populations and fermentation characteristics, Asian-Australasian Journal of Animal Sciences, 28(4), 530-537

Leng, R.A., 2008. Decline in available world resources; implications for livestock production systems in Asia, Livestock Research for Rural Development, 20(1), 2008.

Makkar, H.P.S., Blummel, M., Borowy, N.K., and Becker, K., 1993. Gravimetric determination of tannins and their correlations with chemical and protein precipitation methods, Journal of the Science of Food and Agriculture, 61(2), 161-165. 
Parsons, T.R., Maita, Y. and Lalli, C.M., 1984. A Manual of Chemical and Biological Methods for Seawater Analysis. Pergamon, New York.

Pitta, D.W., Pinchak, W.E., Dowd, S.E., Osterstock, J., Gontcharova, V., Youn, E. and Wickersham, T.A., 2010. Rumen bacterial diversity dynamics associated with changing from bermudagrass hay to grazed winter wheat diets, Microbial Ecology, 59(3), 511-522.

Samsudin, A.A., Evans, P.N., Wright, A.D.G. and Al-Jassim, R., 2011. Molecular diversity of the foregut bacteria community in the dromedary camel (Camelus dromedarius), Environmental Microbiology, 13(11), 3024-3035.

SAS 2012 SAS Institute Inc., SAS OnlineDoc 9. 4 ed. SAS Institute Inc., Cary,

Scheppach, W., 1994. Effects of short chain fatty acids on gut morphology and function, Gut, 35(1), 35-38.

Singh, B., Chaudhary, L.C., Agarwal, N. and Kamra, D.N., 2011. Effect of feeding Ficus infectoria leaves on rumen microbial profile and nutrient utilization in goats, Asian-Australasian Journal of Animal Sciences, 24(6), 810-817.

Valente, T.N.P., da Silva Lima, E., dos Santos, W.B.R., Cesario, A.E.S., Tavares, C.A.J. and de Freitas, M.A.M., 2016. Ruminal microorganism consideration and protein used in the metabolism of the ruminants: A Review, African Journal of Microbiology Research, 10(14), 456-464.

Van Soest, P.J., Robertson, J.B. and Lewis, B.A., 1991. Methods for dietary fiber, neutral detergent fiber, and nonstarch polysaccharides in relation to animal nutrition, Journal of Dairy Science, 74, 35833597.

Yanez-Ruiz, D.R., Moumen, A., Martin Garcia, A.I., and Molina Alcaide, E., 2004. Ruminal fermentation and degradation patterns, protozoa population, and urinary purine derivatives excretion in goats and wethers fed diets based on two-stage olive cake: Effect of PEG supply, Journal of Animal Science, 82(7), 2023-2032. 